\title{
Conventionality and Connection of the Specified Sentence Members with the Specifying Sentence Members
}

\author{
Aygun Memmedova ${ }^{1}$ \\ ${ }^{1}$ Academy of Sciences, Baku, Azerbaijan \\ Correspondence: Aygun Memmedova, Academy of Sciences, Baku, Azerbaijan. E-mail: \\ s.gurbanova@yahoo.com
}

Received: April 12, 2015 Accepted: June 3, 2015 Online Published: July 30, 2015

doi:10.5539/ijel.v5n4p131 URL: http://dx.doi.org/10.5539/ijel.v5n4p131

\begin{abstract}
The article deals with the conventionality and connection of the specified sentence members with the specifying sentence members. The main elements, the morphological and syntactic features of words are investigated. Moreover, the structure of the text, both the rheme and the theme of the sentence, the nuclear of the sentence, and the final point of the sentence are widely researched in the article.
\end{abstract}

Keywords: syntactic units, utterance, specified and the specifying sentence members, syntagm, semantic feature

\section{Introduction}

Modern investigations in the field of syntax, widening of knowledge on this field, realization of analysis in distinctive viewpoints and alongside the language system on the background of coordination and consideration of extralinguistic factors, have succeeded drawing out significant consequences. Modern investigations carried out in this direction make it possible for us to follow the facts that syntax does not only show itself as mutually conventionality of language units on the basis of similarity of semantic coordination, but also they make it possible for us to follow the "revelation" level and forms (ways) of meanings expressed implicitly or explicitly by the speaker's intentions with syntactic units. As professor F. Veysally correctly mentioned in his attempts to determine "The bases of structural linguistics" saying that "taking the meaning as a whole syntax has to the point out the rules of coming of language units in the speech act on a syntagmatic line. Here we must particularly stress two points: 1) study of structural links; 2) study of semantic links. Here we come to conclusion that syntax studies the constructions, possessing implicit or explicit centres, it investigates their structural semantic and pragmatic features" (Veysally, 2008, p. 308). Study of syntactic units from pragmatic aspect makes us study the aim of specification within the sentence, its mechanism of realization and self-belonging features in different languages. Thus study of syntax from pragmatic aspect makes it possible to study the "emphasis" of this or that member of sentence by the means of special specification, revelation of meaning and comparative study of the mechanism of stressing the meaning. Putting in other words, "today, at the modern stage of development of positive sciences, the joining and separating from one another self-belonging features of language and language philosophy are studied as to the conceptual and categorical understanding of each of semiotic and semasiologic layers of the language (Veysalli, 2012).

\section{Scope of the Study}

Taking human factor, the intension of the speaker into consideration has opened a way to the formulation of investigations on the basis of wide specter in the field of syntax and consequently "investigations of cognitive pragmatics" in linguistics took a wide scope. As G. M. Kostyushkina noted acception of "human" (bearer of the language) by the scientific thought paradigm makes it possible particularly accenting on the phenomenon as language situation (Kostyushkina, 2007).

The first problem which we are going to pay attention in the context of analysis of the problem of connection and mutually conventionality of the specified sentence member with the specifying sentence members is associated with the intention of the speech expression, namely with the instance of orientation of speech act. As it is obvious, H. P. Grice in his theory "The meaning theory of the speaker" which can be considered as one of the most important achievements of the XX century science thought, and concretely of the field of pragmatics has succeeded to throw light on a number of points on the intention of the speaker and meaning specifications 
deriving from this intention. As it is also mentioned by E. Abdulrahimov, Grice H. P. Atter's investigation has further developed the theory "Especially noted the difference between what the utterer said, or wanted to say and what he assumed to say" and in this context has specified the following among the notions of "expression ways of the meaning of the utterer": 1) conventional - a member of words and word combinations which are used; 2) non-conventional - the interpretation of the expressed bases upon the conventional usage (Abdulrehimov, 2014). Putting in other words, this theory brings clarity as to conventionality or non-conventionality of the certain units which are to be specified with other sentence members during the moment of utterance. Just the intention of the speaker in the speech utterance "decides" concretely which one of the sentence members needs necessity to be specified, or to be given additional introduction. In this respect during the speech utterance in the frame of the theory on word combinations and sentences serving a certain specifications, "indicating the intention on which the speaker influences" we may include them into group of the protepic utterance (Abdulrehimov, 2014).

Specification phenomenon in speech has not been paid proper attention in the science of linguistics until now and specifying sentence members have been touched upon on a certain degree only in the process of studying other themes. For example, G. S. Kazimov mentioned this problem superficially (Kazimov, 2004). That's why the types of manifestation of links between specifying and specified sentence members naturally may cause discussions. The point is that the phenomenon of specification is formed on the basis of copulative links between specifying and specified sentence members, namely the specified sentence member is not coordinated on the basis of any morphological signs with the specifying sentence member - the grammatical case in which the specified sentence member takes the same sign of case as well, their compositions contain natural parallelism, and on the outer vision they don't seem depending as to the coordination on each other. The specified sentence members together with the specifying sentence member as to the outer appearance of the words and word forms seem to be acting as homogenous members and are considered as homogeneous units. Here we can speak on a certain dependence or subordination only then when the morphological structure of "the whole" is subjected to certain changes. Namely, for example, In the sentence Şəhərin kənarında, çəmənlikdə va meşəlikdə qazılmış xəndəklari bombaladılar, "the whole" şəhərin kənarında agrees with "the parts" çəmənlikdə va meşəlikdə as to the categories of case and quantity, is united with it on the bases of copulative link as a homogenous member. Subordination feature of such a combination becomes "hidden" in implicit manner and appears only on the basis of variation of the case signs of the whole. For example, compare:

Şəhərin kənarl, çəmənlik va meşəlik həmişə istirahat zonası sayıllır.

Şəhərin kənarının, çəmənliyin va meşaliyin havası adamı calb edir.

Şəhərin kənarına, çəmənliya va meşaliya heyran qaldılar.

Şəhərin kənarını, çəmənliyi va meşaliyi bombaladılar.

Şəhərin kənarından, çəmənlikdən va meşəlikdən çoxlu gül-çiçək dərib gatirdilar.

This shows that in the sentence the grammatical attitudes between the specified sentence member expressing the "whole" together with its "part" which is called specifying member exist in any case and in these relations the specified sentence member carries out the subordinating function - the specifying sentence members from the morphological and syntactic view points are in subordination with the "whole". This subordination finds its reflection on one hand on the specified and specifying members' being in the homogeneous relations, in other words "the part's becoming similar with the "whole" as to the morphological structural features, on the other hand, under the influence of the semantic features of the specified "whole" it finds its reflection in the appearance of possibilities of changing as to the grammatical-functional features of the specifying member. Thus, agreement of the specifying member with the specified member is not regular, it bears facultative characterization.

\section{Morphological and Syntactical Analysis of the Specifying and the Specified Members}

The specifying and the specified members of the sentence from the morphological view point can be expressed in the same way or differently.

a) Specified and the specifying sentence member have the same morphological forms, namely, the sentence member which expresses the "whole" subordinates the "part" as to the case and quantity. For example,

The writer, an old man with a white moustache had some difficulty in getting into bed (Sh.Anderson).

Here, the writer being a subject in the nominative case determines the sentence member as an old man with a white moustache to be in the nominative case as well, and by this the "whole" as the writer, an old man with a white moustache is formed as a subject group. 
Also we may compare the following:

Teatrda hamı - Siyavuş özü do, Olikram da bilirdilar ki, Feyzulla ruhani ailasindəndir, atası müfti olub. (Anar)

In this sentence the word hamı being a subject in the nominative case conditions the usage of the words Siyavuş $\ddot{o z} \ddot{u} d$, Dlikram da, which are the specifying members, in the function of subject.

Let's see the example in the Russian language:

На рейде были построены в ряды броненосиы: «Князь Суворов», «Император Александр ІІІ», «Бородино», «Ослабя», «Сисой Великий» и «Наварин»; крейсеры 1-ого ранга: «Аврора», «Адмирал Нахимов», «Дмитрий Донской» и «Светлана»; крейсер 2-ого ранга «Алмаз»; миноносиы: «Беседовый», «Безупречный», «Блестящий», «Бодрый», «Буйный», «Быстрый» и «Бравый». Командовал эскадрой адмирал Рождественский, держа свой флаг на «Суворове». Позднее должны были присоединиться к эскадре броненосеи «Орел» и два крейсера - «Олег» $и$ «Изумруд» (А.Новиков-Прибой).

In the given sentences the subject "броненосцы" (the whole) subordinates the names such as "княз Суворов", "Император Александр III", "Бородино”, "Ослабля", "Сисой Великий” and "Наварин” which have been enumerated in the nominative case, in the same form the subject крейсеры subordinates the names "Аврора", “Адмирал Нахимов", “Дмитрий Донской" and "Светлана", the subject миноносиь subordinates “Беседовый”, “Безупречный”, “Блестящий”, “Бодрый”, “Буйный”, “Быстрый” and "Бравый” which are the names of the ships in the nominative case, plural form, including the word combination "два крейсера" subordinates the names "Олег" and "Изумруд" in the double quantity (in plural form and nominative case).

In the positions, which we speak about, in order to affirm the fact of subordination of the specifying sentence member by the specified sentence member, we may pay attention to the situations in which the morphological form of the "Mass" changes, namely, we can see that they are not used as subjects but as other members of sentence:

This was the occasion of an "at home" to celebrate the engagement of Miss June Forsyte, old Jolyon's granddaughter, to Mr. Philip Bosinney. (J. Galsworthy)

This sentence in the "normal" translation into the Azerbaijani language sounds like this:

"Bu, qoca Colionun nəvasi Miss Cyun Forsaytın Mister Filip Bossini ila adaxlanması şərəfina çağırllmış qonaqliq idi”.

But the original translation as to the grammatical structure sounds like this:

Bu, Miss Cyun Forsaytın, qoca Colionun navasinin Mister Filip Bossini ila adaxlanması şərafina çağıılmı̧̧ qonaqliq idi.

As it is seen word combination "Old Jolyon's granddaughter" explains the name Miss June Forsyte, it specifies the personality of this man. But in the condition of description the expression "of Miss June Forsyte as to the meaning indicates possessive case and acts as the second component (as the object of the sentence taken together) of the word combination; preposition of used within the structure ensures the understanding of the specifying sentence member old Jolyon's granddaughter which is also in the possessive case.

Also in the sentence:

Between him and the four other brothers who were present; James, Swithin, Nicholas, and Roger, there was much difference, much similarity. (J. Galsworthy)

In this sentence the preposition "between" belonging to the both - the preposition him and the word combination the four other brothers, it belongs to the personal names as James, Swithin, Nicholas, Roger as well, and thus the last complex of personal names specifies the adverbial modifier of the sentence (between him and the four other brothers) and it specifies just one adverbial modifier.

Also let's compare:

Həm da ki doğrusu, hər ikisinin - ela Alya xanımın da, Zivar xanımın da ürəklari bir az səksəkali idi. (Anar)

In the given sentence usage of specifying sentence members Alya xanımın da, Zivar xanımın da in the possessive case are subordinated by "the whole" of the both. If this whole were in the other cases of noun the "the part" too would be subordinated by the same case.

Let's compare:

Har ikisinə - Alya xanıma da, Zivar xanıma da (yönlük hal) 
Har ikisini - Alya xanımı da, Zivar xanımı da (təsirlik hal)

Hor ikisina - Alya xanımda da, Zivar xanımda da (yerlik hal)

Hor ikisina - Alya xanımdan da, Zivar xanımdan da (çıxışlıq hal)

Здесь состоялось знаменитое свидание двух императоров: Николая II и Вильгельма II. (А.Новиков-Прибой).

Here the name forms as Николая II и Вильгельма II by being specifying sentence member is completely in subordination to the second part, which is specifying the subject group, from the morphological view point (the specifying sentence member двух императоров demands the following specifying sentence members to be used in the "родительный падеж" as well.

b) The specified and specifying sentence members are expressed by different sentence members and by this time the dependence between them may be broken. For example:

Burada isə yalnız ifadə yox, xasiyyət də sanki başqa idi - açıqürəkli, deyən-gülən, mehriban, yapışıqlı... (Anar)

The homogeneous attributes such as açıqürəkli, deyən-gülən, mehriban, yapışıqlı describe the notion of disposition and specify it as a subject.

c) The specified and specifying sentence members possess different morphological forms, namely the "whole" which is used in one case of the noun is specified by "the part" used in the other case of the noun, here the fact that different parts of speech are used, draws our attention. For example:

No long ago there lived in uptown New York, in a small, almost meager room, though crowded with books, Leo Finkle, a rabbinical student in the Yeshivah University. (B. Malamud)

In the original sentence we find specifying sentence members in three places:

1) in uptown New York, in a small, almost meager room,

2) in a small, almost meager room, though crowded with books,

3) Leo Finkle, a rabbinical student in the Yeshivah University.

In the first case the word combination in a small, almost meager room specifies the adverbial modifier of place in uptown New York and as to the grammar case it depends on it.

In the third case the word combination a rabbinical student in the Yeshivah University specifies the subject Leo Finkle.

However, in the second example below the expression though crowded with books specifies the word room which precedes it, but as to the case it does not agree with it.

Bizi gün çıxanda, hələ qatar gəlib çatmamışdan orada gözlayin.

In this sentence, the adverbial modifier of time qatar galib çatmamışdan specifies the adverbial modifier of time gün çıxanda as a part of time. But though the specified sentence member is in the locative case the specifying member is used in the prepositional case.

Издалека, весьма осторожно он начал накачивать меня политикой. (А.Новиков-Прибой)

In the given sentence the sentence member издалека which is used in the "родительный падеж" is specified by the adverbial modifier of manner весьма осторожно.

The specifying sentence members establish chain gradation vertically, from the upper level downward (Asadov, 1981) and during this time the subordinating line of the specifying member is directed from upper point downward as well. This fact finds its reflection in the attitudes of the specified sentence member with the specifying sentence member as well. Consequently the breach of the whole sentence takes place, a whole independent sentence takes the function of specifying member upon itself and at this time there no morphological dependence takes place between the part in which the specified sentence member participate, and the specifying sentence; thanks to which compound sentence is formulated, for example:

And, motionless, old Jolyon stared at the wall; but for his open eyes, he might have been asleep... (J. Galsworthy)

Və qoca Colion hərəkətsiz halda dayanıb düz qabağındakı divara baxırdı; gözləri açıq olmasa idi, adama elə galardi ki, o yatır. 
Here the sentence but for his open eyes, he might have been asleep by describing the action in the expression old Jolyon stared at the wall serves to specify its manner. Despite this during the specification there is no morphological connection between the "whole" and "the part".

Bu mismarlar müxtəlif səviyyalərdə vurulmuşdular - hündür yerdən vurulanı da vardı və elə aşağıda vurulanları da vardl... (Anar)

In the given example the sentence hündür yerdən vurulanı da vardı və elə aşăğda vurulanları da vardı as a whole explains the piece coming in the preposition, in other words it specifies the manner of the performed action. But here it is impossible to show any morphological connection between the specifying member with the specified one.

В следуюшие дни наступила другая забота: мы должны были надлежащим образом подготовиться к иарскому смотру. (А.Новиков-Прибой)

Here the second given sentence specifies the subject (забота) of the previous sentence. As a whole this sentence can be given in an another form, more in a nut-shell:

В следующие дни наступила другая забота - подготовка к иарскому смотру.

The expression подготовка киарскому смотру which has been transformed into a simple sentence, being able to be used as word combination, can specify the word забота. But the author has not been satisfied with this version and by expressing the serious preparation of the sailors for the forthcoming tsar inspection has expanded the construction of the specifying member and established a separate sentence.

In all these cases we need to speak about not morphological problems between the specified sentence member with the specifying one, but we need speaking of the problems of semantic-syntactic relations taking place between them.

Observations show that generally in the literary texts usage of such various versions related to the specifying sentence members more often takes place in the author's speech and partially it refers to the incomplete direct speech.

We should also mention that during the investigation of actual division of specifying sentence member it is necessary to pay special attention to the problem of differentiation of these units. Thus, as it is known to us, in the text new and the old are expressedlin separate syntagms. That's why in order to differentiate the old with the new one text is divided into sentences and sentences in their turn are divided into the syntagms and become sentence members. Such an ability of the text or sentence to be divided is called actual division of text or sentence. The result of structural analysis of the text gives us materials for the specification of the actual division of the sentence. During the analysis of the structure of the text both the rheme and the theme of the sentence, the known to us notion, the new notion, the nuclear of the sentence, the final point of the sentence, they all bear importance in the same degree. For the investigator alongside the presence of certain meaningful elements in the sentence, the manner of distribution of the elements which are necessary for the systematization of the text in relation with one another is of more interest as well (Asadov, 1981).

Generally speaking during the differentiation of theme and rheme in the sentence intonation plays a special role. This can be observed in the specimens of the specified and specifying sentence members.

The specified and the specifying sentence members both together establish one syntagm. At this time the specifying sentence members manifest as word, word combination and even in the form of sentence. At the same time the attitudes between the specified member with the specifying member as to the syntagmatic relations find their reflection in the form of word combinations. As it is known to us, when we say word combination we mean to say combination of usually two or more words entering the parts of speech and having independent meanings, expressing a certain undivided notion or imagination joined in a grammatical union.

Here when the authors say "undivided" they mean not grammatical division, but actual division, namely, as the specified sentence member creates unity with the specifying member, is not subjected to redivision again. This structure can be divided only grammatically "In fact actual division does not deny grammatical division and it can't deny in any way, because these are different points of view" (Rozental \& Telenkova, 1976).

\section{Conclusion}

Thus, in the sentence it is possible to find the specified and specifying members as rheme and theme as to the intonation: the specified member reflects theme, but the specifying one reflects rheme in the sentence. They both together establish one syntagm. The result of structural analysis of the text proves that both the rheme and the 
theme of the sentence, the known to us notion, the new notion, the nuclear of the sentence, the final point of the sentence all bear importance in the same degree.

\section{References}

Abdulrahimov, E. (2014). Linguistic Pragmatics. Baku: Science and Education.

Arnold, I. V. (2006). Stylistics of Modern English. M. Rlinta/Nauka.

Asadov A. A. (1981). Actual articulation of sentence in Azerbaijani and English (subject as the expression of rema). Baku.

Kazımov, G. S. (2004). Modern Azerbaijani language. Syntax, Baku: Azpoliglot Ltd.

Kostyushkina, G. M. (2007). Cognitive pragmatics. Tolyatti, TSU.

Rozental, D. Y., \& Telenkova, M. A. (1976). Reference Dictionary of linguistic terms. M. Prosvesheniye.

Veysally, F. Y. (2008). Bases of structural linguistics. Studia philologica. Baku: Mutarjim.

Veysalli, F. Y. (2012). Sign, the meaning and content of the concepts. Language Researches.

\section{Copyrights}

Copyright for this article is retained by the author(s), with first publication rights granted to the journal.

This is an open-access article distributed under the terms and conditions of the Creative Commons Attribution license (http://creativecommons.org/licenses/by/3.0/). 